\title{
POLICE LIABILITY FOR NEGLIGENT INVESTIGATIONS: WHEN WILL A DUTY OF CARE ARISE?
}

\section{MANDY SHIRCORE*}

[In 1988 in Hill v Chief Constable of West Yorkshire, the House of Lords denied a duty of care was owed by police to a victim of a serial murderer. The case was interpreted as immunity from negligence actions for police when involved in the suppression and investigation of crime'. Recent cases in Australia and the United Kingdom have confirmed that while blanket immunity from negligence actions for police involved in investigatory functions does not exist, plaintiffs alleging negligence will face considerable difficulties establishing a duty of care was owed. The recent cases provide an opportunity to re-examine the appropriate tests to apply in determining the existence and scope of police duty of care and to reassess the policy grounds underlying the decisions. In doing so the article argues that Australian courts should avoid the UK approach of applying a broad exclusionary rule particular to police, as sufficient safeguards already exist in the Australian High Court's duty of care formulation for public authorities.]

\section{INTRODUCTION}

There is no doubt that police officers owe a duty to protect the public. ${ }^{1}$ The translation of the duty to a private duty in the developing tort of negligence is however contentious. The first element necessary in conversion of the public

\footnotetext{
* Associate Lecturer, James Cook University. I would like to thank Tracey Carver and the anonymous referees for their helpful comments on earlier drafts of this article.

${ }^{1}$ See generally Hill v Chief Constable of West Yorkshire [1989] AC 53 ('Hill'), 241; Peat v Lin [2004] QSC 219, [10]; Police Services Administration Act 1990 (Qld) s 10.5.
} 
duty to a private duty in negligence is establishing that the defendant owes a duty of care to the plaintiff. Without a duty being owed, harm caused to the plaintiff by the defendant's negligent conduct is without redress. ${ }^{2}$

Ever since Lord Aitkin's neighbourhood test was propounded in Donoghue $v$ Stevenson, ${ }^{3}$ the courts have struggled with its application to harm caused to the plaintiff by the defendant's omission to act. Foreseeability of injury is not enough, but defining exactly what is required has proved illusive. When coupled with the long held view that there is generally no common law duty to rescue another ${ }^{4}$ or protect another from harm inflicted by a third party, ${ }^{5}$ the issue of when and in what circumstances a police authority, who's functions include rescue and protection, owe a duty of care in negligence is similarly unclear.

In 1988, the House of Lords, citing lack of proximity and public policy grounds, denied a duty of care was owed by police to a victim of a serial murderer. ${ }^{6}$ The case was interpreted as immunity from negligence actions for police when involved in the 'suppression and investigation of crime'? Treatment of the Hill decision by subsequent courts in the United Kingdom came under criticism by the European Court of Human Rights. ${ }^{8}$ Despite this, recently the House of Lords confirmed that public policy grounds operate to deny a duty of care owed to victims of crime in relation to investigative functions of police.' The Hill immunity, although not endorsed in its 'full breadth', was applied in Brooks ${ }^{10}$ to deny a right of action in negligence to a victim of 'a litany of derelictions of duty and failure in police investigation.' 11

\footnotetext{
${ }^{2}$ Where police conduct amounts to intentional torts such as assault, battery or false imprisonment a cause of action will arise. This paper focuses purely on police liability for negligent conduct in situations where the intentional torts do not also arise. ${ }^{3}$ [1932] AC 562, 580.

${ }^{4}$ Stovin v Wise [1996] AC 923 (HL); For discussion of the general rule see Natalie Gray and James Edelman 'Developing the law of omissions: a common law duty to rescue?' (1998) 6 Torts Law Journal 18.

${ }^{5}$ Modbury Triangle Shopping Centre Pty Ltd v Anzil (2000) 205 CLR 254 (Modbury). ${ }^{6}$ Hill [1989] AC 53.

${ }^{7}$ See, eg, Osman v Ferguson [1993] 4 All ER 344 ('Osman'); Hughes v National Union of Mineworkers [1991] 4 All ER 278 ('Hughes'); Elguzouli-Daf v Commissioner of Police of the Metropolis [1995] QB 335.

${ }^{8}$ Osman v. United Kingdom - 23452/94 [1998] ECHR 101 (28 October 1998).

${ }^{9}$ Brooks $v$ Commissioner of Police for the Metropolis [2005] UKHL 24 ('Brooks').

${ }^{10}$ Ibid.

${ }^{11}$ Ibid [8].
} 
Other jurisdictions have not felt it necessary to embrace the notion of public policy immunity for police in the suppression and investigation of crime. ${ }^{12}$ In canvassing comparative law, Lord Bingham, in Brooks, acknowledged the opposing approaches in Canada and South Africa, and referred to the Australian High Court's decision in Sullivan v Moody ${ }^{13}$ as being 'generally' consistent with the reasoning in Hill. ${ }^{14}$ The existence and scope of the duty owed by police in the investigation and suppression of crime has not been directly considered by the High Court of Australia, although support for the UK approach is evident in a number of judgments. Consistent with the difficulties in determining the existence of a duty of care in novel cases, state courts have struggled in a number of recent decisions with defining the scope of the duty of care owed by police. ${ }^{15}$

As was noted in Brooks it can no longer be said that police enjoy unquestionable public confidence that they will apply 'their best endeavours to the performance' of their functions. ${ }^{16}$ Fear of terrorist attacks has led to unprecedented widening of police powers, deepening concerns among civil libertarians that human rights abuses against those under investigation may be sanctioned. Within this turbulent climate, the fine balancing act between police accountability and the requirement for police discretion and freedom of investigation becomes more acute. With these concerns in mind, this article seeks to explain the existence and scope of police liability in negligence in Australia.

In part two the article defines what is meant by immunity in law. Part three traces the development of police liability in negligence in the United Kingdom, how it has been dealt with in other jurisdictions and recent

\footnotetext{
${ }^{12}$ Doe v Metropolitan Toronto Board of Commissioners of Police (1998) 160 D.L.R. (4 $\left.4^{\text {th }}\right) 697$ ('Doe'); Odhavji Estate v Woodhouse [2003] 3 SCR 263; Carmichele v Minister of Safety and Security (2001) 12 BHRC 60; Whithair v Attorney General (1996) 2 NZLR 45.

${ }^{13}$ (2001) 207 CLR 562.

${ }^{14}$ Brooks $v$ Commissioner of Police for the Metropolis [2005] UKHL 24 referring to Sullivan v Moody [2002] CLR 251, [57], [60].

${ }^{15}$ Quintano v New South Wales [2002] NSWCA 278; Wilson v State of New South Wales [2001] NSWSC 869, Peat v Lin \& ors [2004] QSC 219; Cran v State of New South Wales [2004] NSWCA 92; Tahche v Abboud and Others [2002] VSC 36; Zalewski and Anor v Turcarolo [1995] 2 VR 562; Gibbs v Commissioner of Police and Queensland [2000] QCA 33; Batchelor v State of Tasmania (2005) Aust Torts Reports 81-782.

${ }^{16}$ Brooks [2005] UKHL 24, [28] (Lord Steyn).
} 
treatment of the principles in Australian cases. Part four will discuss the policy considerations which have justified the imposition of a 'no-duty' or 'public policy immunity' rule in the UK, a rule adopted at least in part by Australian courts.

This analysis will demonstrate that there are two possible courses open to Australian courts in determining whether police owe a duty of care in particular circumstances. The first is to follow the UK approach, which adopts a broad 'no-duty' rule, to which few exceptions have been found; the second is to apply to police the general principles developed by the High Court of Australia applicable to the determination of duty of care owed by public authorities. ${ }^{17}$ This second approach treats the relevant policy arguments as one of a number of possible salient features to be measured in determining whether a duty of care is owed. ${ }^{18}$

It will be argued that the United Kingdom approach has resulted in inconsistent and flawed attempts to justify exceptions to the immunity principle. Further it will be argued that some of the public policy grounds enunciated in Hill are outdated and require reconsideration. The paper concludes that there are sufficient principles ${ }^{19}$ that Australian courts have imposed on the duty of care owed by public authorities charged with investigative functions and the duty owed to protect a person from harm by third parties to adequately limit liability of police authorities. Care must be taken not to elevate policy considerations to the status of 'immunity', irrespective of qualification.

\footnotetext{
${ }^{17}$ See Graham Barclay Oysters Property Ltd v Ryan (2002) 211 CLR 540; Sullivan v Moody (2001) 207 CLR 562.

${ }^{18}$ Crimmins v Stevedoring Industry Finance Committee (1990) 200 CLR 1, [93]

(McHugh J).

${ }^{19}$ These could equally be described as policies. Note Jane Stapleton's argument in 'The golden thread at the heart of tort law: Protection of the vulnerable' (2003) 24 Australian Bar Review137 that distinguishing between principle and policy is artificial and the terminology should be 'ditched' in favour of a neutral description of 'legal concerns'.
} 


\section{What Is MEANT By IMMUNITY IN LAW?}

Put simply, immunity refers to an exemption from liability, or an exemption from the duties imposed by law, generally on grounds of public policy. ${ }^{20}$ The mechanism by which the exemption is granted in negligence is, at the first stage of the analysis, the duty of care.

In discussing the utility of the duty concept as a means of containing liability in negligence, Jane Stapleton argues that '[i]t is a particularly efficient way of signalling countervailing systemic factors because it allows a coherent presentation of a no-liability outcome even in those cases where the conduct of the defendant was unreasonable and where, therefore, it is not possible to resort to "no-breach' justification. ${ }^{21}$ In situations where the relationship between the parties, will always give rise to the no-liability outcome, due to explicit countervailing factors, it may be argued that immunity from liability exists.

A conclusion that immunity from liability exists in relation to a particular situation or relationship must however be carefully drawn. In Darker $v$ Chief Constable of the West Midlands Police ${ }^{22}$ where the court was examining the scope of the witness 'absolute immunity' rule as applied to police evidence and investigatory work, Lord Clyde noted:

It is temptingly easy to talk of the application of immunities from civil liability in general terms. But since the immunity may cut across the rights of others to a legal remedy and so runs counter to the policy that no wrong should be without a remedy, it should only be allowed with reluctance, and should not be readily extended. ${ }^{23}$

\footnotetext{
${ }^{20}$ See for eg Darker v Chief Constable of the West Midlands Police [2001] 1 AC 435; D'Orta-Ekenaike v Victoria Legal Aid (2005) 214 ALR 92.

${ }^{21}$ Jane Stapleton, 'Duty of Care: Peripheral parties and alternative opportunities for deterrence', [1995] 111 The Law Quarterly Review 301, 303. Stapleton defines a 'countervailing factor' as 'one which the courts find persuasive in justifying the decision not to impose liability whenever it is present, even if the defendant in a particular case had clearly been careless and caused an actionable form of damage to the plaintiff.'

${ }_{22}^{22}$ [2001] 1 AC 435 ('Darker').

${ }^{23}$ Ibid 456.
} 
While it may prove difficult to mark the precise bounds of a particular situation giving rise to immunity from liability, thereby requiring some variance in application, '[o]nce a situation has been identified as deserving of immunity it may readily be accepted that the immunity is in its quality absolute'. ${ }^{24}$

Recent confirmation in Australia of the advocate's immunity for work done in court or 'work intimately connected with' work in court is an example of immunity from liability. ${ }^{25}$ Like other parties in the courtroom procedure, ${ }^{26}$ the advocate's immunity from an action in negligence in relation to court work is absolute. Although argument may arise as to how the boundaries of 'conduct that is intimately connected with in-court conduct ${ }^{27}$ be defined, this is not a problem that affects the relationship between the parties significantly. ${ }^{28}$ It is therefore suggested that labelling of the advocate's 'no-liability outcome' at the duty stage, as immunity from liability in negligence, is justified and as a rule is well understood. ${ }^{29}$

Other situations of "no-duty, ${ }^{30}$ are not readily categorized as an immunity from liability in negligence, because, it is argued, the explanation underlying the no-duty outcome is too widely drawn or based on factual determinations and terminology, not capable of identification as an immunity. ${ }^{31}$ An immunity suggests a blanket exemption from liability to which the rest of the world is subject, rather than a general principle of law based on 'countervailing factors' which may apply to the factual situation at hand and from which exceptions may exist.

\footnotetext{
${ }^{24}$ Ibid 457.

${ }^{25}$ D'Orta-Ekenaike v Victoria Legal Aid (2005) 214 ALR 92 ('D'Orta').

${ }^{26}$ The immunity applies equally to judges, witnesses and prosecutors.

${ }^{27} D^{\prime}$ Orta (2005) 214 ALR 92, [95].

${ }^{28}$ The application in D'Orta of the immunity to 'conduct that is intimately connected with in-court conduct' was left unchanged from the original High Court decision in Giannerelli v Wraith (1988) 165 CLR 543.

${ }^{29}$ While it may be relatively easy to define it has been argued that the advocates' immunity it is not the most coherent rule. See Peter Cane, 'Case Note: The new face of advocates' immunity' [2005] 13 Torts Law Journal 93 where he argues that the High Court's decision in D'Orta, has failed to provide a rationally argued outcome, leaving 'the law in a state of confusion'.

${ }^{30}$ Examples of 'no-duty' situations include no general duty to rescue Stovin $v$ Wise [1996] AC 923 (HL), no general duty to protect from third party harm Modbury (2000) 205 CLR 254.

${ }^{31}$ See Stapleton, above n 21, 303 where she argues that courts have often masked the 'normative reasoning' behind identification of 'countervailing systemic factors' in 'factual terminology'.
} 
In Barrett $v$ London Borough of Enfield, ${ }^{32}$ Lord-Browne-Wilkinson commented

Although the word 'immunity' is sometimes incorrectly used, a holding that it is not fair, just and reasonable to hold liable a particular class of defendants whether generally or in relation to a particular type of activity is not to give immunity from a liability to which the rest of the world is subject. ${ }^{33}$

\section{A Can it be said that the police enjoy immunity from liability?}

While Australian courts have rejected the United Kingdom's three-stage Caparo $^{34}$ test that asks, after a determination of foreseeability and proximity, whether the imposition of liability in the particular circumstances is fair, just and reasonable, the application of policy considerations to the determination of duty of care is fundamental in both jurisdictions. ${ }^{35}$ The Australian approach to novel duty of care cases proceeds by way of analogy to apply in an incremental fashion, material or salient factors relevant to the particular factual situation at hand. ${ }^{36}$ In Sullivan v Moody ${ }^{37}$ the High Court referred to the various classes of problems that may bear upon the determination of a

${ }^{32}$ [1999] 3 All ER 193.

33 Ibid 197. See also, X and Others v Bedfordshire County Council [1995] 2 AC 211, where denial of a duty of care being owed by local authorities to children in its care has not led to 'immunity' from liability. What the case has done is to provide 'countervailing systemic factors', which have been applied in analogous cases to help signal the bounds of the no-liability outcome.

${ }^{34}$ Refers to the three-stage test, employed by the UK courts to determine the existence of a duty of care in novel cases. First enunciated in Caparo Industries Plc v Dickman [1990] 2 AC 605. although pursued for some time by Kirby J, Pyrenees Shire Council $v$ Day (1998) 192 CLR 330; Perre v Appand Pty Ltd (1999) 198 CLR 180; Crimmins $v$ Stevedoring Industry Finance Committee (1990) 200 CLR 1, the test was clearly rejected by the High Court in Sullivan v Moody(2001) 207 CLR 562, [49].

${ }^{35}$ See, eg D A Ipp, 'Policy and the swing of the negligence pendulum' (2003) 77 Australian Law Journal 732, where he discusses the influence of policy on the law of negligence; Kylie Burns 'The way the world is: Social facts in High Court negligence cases' (2004) 12 Torts Law Journal 215.

${ }^{36}$ See, eg, Perre v Appand Pty Ltd (1999) 198 CLR 180; Sullivan v Moody (2001) 207 CLR 562.

${ }^{37}(2001) 207$ CLR 562. 
duty ${ }^{38}$ Once the problem is identified it "will then become the focus of attention in judicial evaluation of the factors which tend for or against a conclusion to be arrived at as a matter of principle. ${ }^{39}$

While application of the material or salient factors may provide a coherent body of persuasive factors militating against a duty of care finding in relation to particular situations or relationships, such could rarely be described as giving rise to immunity from liability in the sense described above. This is not to say that the findings do not, at least where explicitly and rationally stated, signal to potential plaintiffs the possible limits to liability arising from their relationship with the defendant. Despite Justice McHugh's recent comments that immunity is just another name for a conclusion that a defendant owes no actionable duty of care in a particular circumstance, ${ }^{40}$ it is argued that to label a particular relationship, even in defined circumstances, as giving rise to immunity from liability is misleading. Only in the few situations where an absolute outcome of no-liability is present, such as for advocates, can the label of immunity from liability be given.

Labelling the relationship between the police and members of the public in relation to the suppression and investigation of crime as giving rise to immunity from liability for negligence is similarly misleading. Even in the United Kingdom, where the protection from liability afforded to police is extensive, such forms of labelling have been subject to judicial criticism. ${ }^{41}$

In Australia, despite support by the courts for the decision in $\mathrm{Hill}^{42}{ }^{42}$ it has been acknowledged that there is no absolute immunity for police from negligence claims in relation to the investigation and suppression of crime. As Atkinson J recently stated ' $[\mathrm{t}]$ here is ... no binding authority that police

\footnotetext{
${ }^{38}$ These include the type of harm suffered by the plaintiff, including harm caused by the criminal conduct of third parties, the powers and discretion of statutory authorities, indeterminacy and conflicts with other duties or legal principles. Sullivan $v$ Moody ibid [50].

${ }^{39}$ Sullivan v Moody (2001) 207 CLR 562 [50] footnotes omitted.

${ }^{40}$ D'Orta (2005) 214 ALR 92, [100], [101].

${ }^{41}$ See, eg, Osman v. United Kingdom - 23452/94 [1998] ECHR 101 (28 October 1998) and Brooks [2005] UKHL 24, [27]. Note also comments by Lord Bingham of Cornhill in $J D(F C)$ (appellant) v. East Berkshire Community Health NHS Trust (FC) [2005] UKHL 23 [25].

${ }^{42}$ See, eg Sullivan v Moody (2001) 207 CLR 562, [56] [57], Tame v New South Wales (2002) 211 CLR 540, 562 and the numerous state court decisions referred to below.
} 
officers enjoy a blanket immunity from liability in tort in the investigation and prevention of crime although they are "generally exempt" from liability., 43

Accepting, as is appropriate, that there is no immunity from negligence actions for police, any inquiry into the duty owed by police should proceed, once foreseeability is established, on the basis that policy considerations may be applicable as part of the balancing of salient factors. ${ }^{44}$ This does not imply that for every factual situation the courts must engage in an arduous exploration of each of the factors anew. As will be discussed there are policy considerations arising from the statutory and common law functions of public authorities charged with investigatory functions that have attracted sound 'countervailing systemic factors' in certain circumstances, militating against a duty finding. However it is the methodology, adopted in the UK and in some Australian courts, which proceeds on the basis that all police investigative functions are immune from liability in negligence on public policy grounds, and from which exceptions are applied, which is criticised in the following section as failing to provide a principled body of law.

\section{The Development of Police Liability in Negligence}

\section{A United Kingdom}

Prior to the decision in Hill, it was acknowledged that, in certain circumstances, police conduct may give rise to a duty of care. In Hill, Lord Keith referred to cases where a person had been injured as a 'direct result' of the officer's positive acts and omissions as examples where liability had been held to exist. ${ }^{45}$ Other examples of liability include negligent driving by police in the performance of their duties, and instances where the police conduct also gives rise to intentional torts. ${ }^{46}$ It is suggested that the rationale for these latter

${ }^{43}$ Peat v Lin [2004] QSC 219, [24] footnotes omitted.

${ }^{44}$ Graham Barclay Oysters Property Ltd v Ryan (2002) 211 CLR 540; Crimmins v Stevedoring Industry Finance Committee (1990) 200 CLR 1; Sullivan v Moody (2001) 207 CLR 562, [49].

${ }^{45}$ Hill [1989] AC 53, 55 (Lord Keith). Cases referred to were Knightley v Johns [1982] 1 All ER 851; Rigby v Chief Constable of Northamptonshire [1985] 2 All ER 985.

${ }^{46}$ See, eg, Gaynor v Allen [1959] 2 QB 403, Johnstone v Woolmer (1977) 16 ACTR 6, Blight $v$ Warman and McAllan [1964] SASR 164 all referred to by Brooking J in Zalewski v Turcarolo [1995] 2 VR 562, Victoria v Horvath [2003] VSCA 24. 
cases can be explained by the undemanding test of foreseeability that is applied almost exclusively in cases where physical harm is the direct result of the defendant's conduct. ${ }^{47}$

Where it is alleged the police were negligent in their investigative functions, different and more complex considerations have been held to apply. This issue was first addressed in Hill. The case concerned police conduct in the investigation of serial murders. The mother of the last victim brought an action alleging police negligence in failing to apprehend the accused prior to the death of her daughter. ${ }^{48}$ Lord Keith, concerned with indeterminate liability, relied on the absence of 'a special relationship' between the victim and the police in denying a duty of care. ${ }^{49}$ In Hill the victim was said to be one of a "vast number of the female general public who might be at risk from his activities but was at no special distinctive risk in relation to them' ${ }^{50}$ This lack of proximity and absence of a 'special relationship' has since been applied in a number of cases to deny a duty of care in situations where the harm to the plaintiff has been caused by the negligent or criminal conduct of a third party. ${ }^{51}$

\footnotetext{
${ }^{47}$ See M Davies and I Malkin, Butterworths Tutorial Series: Torts, (2003) pp 109, 116; H Luntz, D Hambly, Torts Cases and Commentary (2002). See also, McHugh in D'Orta-Ekenaike v Victoria Legal Aid (2005) 214 ALR 92, where at [101] he states 'Reasonable foreseeability of physical harm is generally enough to impose a duty of care on a person who knows or ought to ought reasonably foresee that physical harm is a likely result of his or her conduct'. The police exceptions to this principle that McHugh J refers to are not instances of 'direct' physical harm caused by the defendant police, but indirect harm caused by a failure to control a third party.

${ }^{48}$ For a detailed critique of the investigation in Hill, including the reasons why the plaintiff brought the claim, see Joan Smith, Misogynies: Reflections on Myth and Malice (1989) 117-151.

${ }^{49}$ Hill [1989] AC 53, 57. The case was distinguished from the earlier decision of Home Office v Dorset Yacht Co Ltd [1970] 2 All ER 294 where prison officers were held to owe a duty of care to surrounding property owners when they failed to prevent the escape of boys in their custody. In Dorset the defendant's knowledge of the detainees propensity to escape and the 'exceptional' risk to those whose property was in close proximity gave rise to the limited duty of care. (Lord Diplock).

${ }^{50}$ Hill [1989] AC 53, 57 (Lord Keith).

${ }^{51}$ See, eg, Ancell v McDermott [1993] 4 All ER 355; Clough v Bussan [1990] 1 All ER 431; Alexandrou v Oxford [1993] 4 All ER 328. These cases involved 'pure omissions' and may be contrasted with situations where the police took control of the situation, provided protection for members of the public and then negligently withdrew from the scene. In these cases a sufficient relationship of 'proximity' had been created and a duty of care arose. See, eg Gibson (AP) v Orr; Chief Constable Strathclyde Police [1999] Scot CS 61 and O'Rourke v Schacht (1974) 55 D.L.R $\left(3^{\text {rd }}\right)$ 96.
} 
To ensure the path was blocked for future plaintiffs, ${ }^{52}$ Lord Keith enunciated a number of public policy grounds supporting a 'no-duty' finding. ${ }^{53}$ Drawing an analogy from the barrister's immunity then in force, ${ }^{54}$ he held police immune from action 'of this kind', as to impose a duty 'may lead to the exercise of a function being carried on in a defensive frame of mind. ${ }^{55}$ Further he argued that the nature of police investigative work required decisions to be made on matters of policy and discretion and

[m]any such decisions would not be regarded by the courts as appropriate to be called into question ... A great deal of police time, trouble and expense might be expected to have to be put into the preparation of the defence to the action ... The result would be a significant diversion of police manpower and attention from their most important function, that of the suppression of crime. ${ }^{56}$

It has been argued that the effect of Hill 'was to recast tort law as the enemy, not the instrument, of public policy'. ${ }^{57}$

\section{B Treatment of the Hill decision}

Over the next decade in the UK, Hill was elevated to a 'doctrine of immunity' for police when performing investigatory functions. Initially interpreted as applying primarily to police policy and discretionary decisions, it was extended to operational decisions 'taken in the course of attempts to control serious public disorder'. ${ }^{58}$ Negligence claims made by accused persons against prosecuting authorities failed on similar policy grounds, namely that

\footnotetext{
${ }^{52}$ Laura Hoyano 'Policing Flawed Police Investigations: Unravelling the Blanket' (1999) 62 The Modern Law Review 912.

${ }^{53}$ This was arguably obiter dicta comments of Lord Keith which have become the focal point in many cases since. Lord Templeman similarly referred to policy grounds as the reason for denying a duty of care was owed. In Hughes [1991] 4 All ER 278, May J refers to the policy grounds as obiter dicta, cf Lord Bingham in Brooks [2005] UKHL 24, [19], where he refers to this as part of the ratio decidendi of Hill.

${ }^{54}$ Rondel v Worsley [1987] 1 All ER 1173. But note the House of Lords has since abolished the immunity Hall $v$ Simon [2000] 3 WLR 543.

${ }_{55}^{55}$ Hill [1989] AC 53, 57.

${ }^{56}$ Ibid 59.

${ }^{57}$ Hoyano above $\mathrm{n} 52,912$.

${ }^{58}$ Hughes [1991] 4 All ER 278.
} 
to impose a duty would inhibit the functions and duties of the authority, exhausting valuable time and resources. ${ }^{59}$

In 1998, the European Court of Human Rights held that the Court of Appeal's approach to police negligence actions in the case of Osman $v$ Ferguson ${ }^{60}$ 'proceeded on the basis that the [immunity] rule provided a watertight defence to the police and that it was impossible to prise open an immunity which the police enjoy from civil suit in respect of their acts and omissions in the investigation and suppression of crime'. ${ }^{61}$ The ECHR held that this breached Article 6 of the European Convention on Human Rights, by denying the plaintiffs the opportunity to have their matter heard on the facts before a tribunal. ${ }^{62}$ The ECHR's decision brought criticism from domestic courts and commentators, and recent findings by the ECHR have tempered the original findings. ${ }^{63}$

Post Osman, courts in the UK have been generally cautious to ensure that the Hill policy considerations have been dealt with within the framework of the three-stage Caparo test. ${ }^{64}$ Within this framework the courts have acknowledged that the stages are not distinct and often overlap, so that in the

\footnotetext{
${ }^{59}$ See, eg, Elguzouli-Daf v Commissioner of Police of the Metropolis[1995] QB 335; Mesigna v Commissioner Australian Federal Police[2001] ACTSC 46; Cran v New South Wales [2004] NSWCA 92.

${ }^{60}$ [1993] 4 All E.R. 344.

${ }^{61}$ Osman v. United Kingdom - 23452/94 [1998] ECHR 101. In Osman v Ferguson the claimant was the victim of third party criminal conduct and he claimed that despite clear warnings and requests for assistance from the police, the police had negligently failed to protect him and his father. cf Van Colle v Hertfordshire Police [2006] EWHC 360 (QB).

${ }_{62}$ The relevant part of the European Convention on Human Rights provides (Article 6.1) 'In the determination of his civil rights and obligations....everyone is entitled to a hearing by $[\mathrm{a}]$....tribunal'.

For discussion of the ECHR's findings in Osman $v$ United Kingdom see Rt Hon Lord Hoffman 'Human Rights and the House of Lords' (1999) 62 Modern Law Review 159; L Hoyano above n 52; T. Wier 'Down Hill all the Way?' (1999) 58 Cambridge Law Journal 4.

${ }^{63} Z$ v United Kingdom (application no. 2939/95) the ECHR noted that the use of the third stage of the Caparo test, alleviate earlier concerns in Osman of the operation of a blanket immunity for police, [99].

${ }^{64}$ See, eg, Brooks [2005] UKHL 24; Cowan v The Chief Constable for the Avon and Somerset Constabulary [2001] EWCA Civ 1699.
} 
rare 'exceptional cases' where a 'special relationship' exists - generally as a result of an assumption of responsibility ${ }^{65}$ - policy considerations may be outweighed.

There have, however, been few exceptions found on this basis. In a case where a senior police officer failed to assist a junior officer who was assaulted by a person in custody, a duty of care was held to exist based upon the degree of responsibility assumed by the defendant for the plaintiff's safety. ${ }^{66}$ Similarly a duty was held to exist where the negligent failure of police to keep the identity of an informer confidential resulted in threats of violence and consequent psychiatric harm to the plaintiff. ${ }^{67}$ In strike-out proceedings, the court held that it was arguable that proximity was satisfied as the police had assumed responsibility for the anonymity of the particular plaintiff, thereby creating a 'special relationship' justifying the imposition of a duty. The court held that competing public policy considerations particular to police informers regarding confidentiality and anonymity outweighed the Hill policy arguments. ${ }^{68}$ What will amount to an 'assumption of responsibility' sufficient to warrant this exception to the core Hill principle is unclear. ${ }^{69}$

Despite some commentators suggesting that the ECHR's findings in Osman caused 'a wholescale retreat from public policy immunity ${ }^{70}$ it is arguable that

${ }^{65}$ See, eg, Brooks [2005] UKHL 24, [29], The Chief Constable of Northumbria v Costello [1998] EWCA Civ 1898, Swinney v Chief Constable of Northumbria [1996] 3 All ER 449 ('Swinney').

${ }^{66}$ The Chief Constable of Northumbria v Costello [1998] EWCA Civ 1898. . Cf however Hughes [1991] 4 All ER 278, where despite the employment situation, no duty was held to exist for an operational decision made by a senior officer in relation to a serious public disorder.

${ }^{67}$ Swinney [1996] 3 All ER 449. Another exception was found in the case of Kirkham $v$ Chief Constable of the Greater Manchester Police [1992] WLR 987 where the police were held to owe a duty to advise the prison authority of the plaintiff's suicidal tendencies.

${ }^{68}$ Swinney [1996] 3 All ER 449. In this case the court treated the public policy grounds as a possible defence to the claim which was considered after a duty was found to exist.

${ }^{69}$ Cf Hughes [1991] 4 All ER 278, no assumption of responsibility. But also cf Van Colle v Hertfordshire Police [2006] EWHC 360 (QB).

${ }^{70}$ Rosalind English 'Forensic Immunity Post-Osman' (2001) 64 Modern Law Review 300 at 306, where she refers to a number of cases since Osman where the House of Lords have demonstrated 'a wholescale retreat from public policy immunity'. None of the cases however, were concerned with allegations of police negligence in the investigation or suppression of crime but with duties owed by other public authorities. 
the most recent pronouncements by the House of Lords demonstrate a return to the broad exclusionary rule enunciated in Hill. While the Lords, in Brooks, ${ }^{71}$ were willing to concede that there may be exceptional cases where exceptions to Hill were justified, ${ }^{72}$ and that the principle in Hill should be 'reformulated in terms of the absence of a duty of care rather than a blanket immunity, ${ }^{73}$ the court was not willing to depart from the core sentiments and findings in Hill.

In Brooks the plaintiff alleged police negligence in the treatment of him as a victim and witness of a serious crime. Despite the clear evidence of gross negligence ${ }^{74}$ the court held:

A retreat from the principle in Hill would have detrimental effects for law enforcement. Whilst focusing on investigating crime, and the arrest of suspects, police officers would in practice be required to ensure that in every contact with a potential witness or a potential victim time and resources were deployed to avoid the risk of causing harm or offence. Such legal duties would tend to inhibit a robust approach in assessing a person as a possible suspect, witness or victim. By placing general duties of care on the police to victims and witnesses the police's ability to perform their public functions in the interests of the community, fearlessly and with despatch, would be impeded. It would, as was recognised in Hill, be bound to lead to an unduly defensive approach in combating crime. ${ }^{75}$

Similar to the general approach in UK cases, Brooks proceeded before the House of Lords on the basis that the Hill principles applied. An exception sought by the applicant, namely that a duty arises where the harm is caused by the direct positive acts or omissions of police, as distinct from the indirect harm caused to the victim in Hill, was dismissed by the court.

\footnotetext{
${ }^{71}$ Brooks [2005] UKHL 24.

${ }^{72}$ Ibid, [6] (Lord Nicholls).

${ }^{73}$ Ibid [27] (Lord Steyn).

${ }^{74}$ Matter had been dealt with by public enquiry (The Stephen Lawrence Inquiry: Report of an Inquiry by Sir William MacPherson of Cluny (1999) Cm 4261-I), so that issues of fact were not in dispute.

${ }^{75}$ Brooks [2005] UKHL 24, [30].
} 
The United Kingdom cases demonstrate the difficulties plaintiffs encounter in attempting to avoid the broad exclusionary or 'immunity' rule that is applied in actions alleging police negligence in the investigation of crime. Arguments raised by plaintiffs to justify exceptions to the rule based on operational/policy decisions, ${ }^{76}$ direct and indirect harm, ${ }^{77}$ operational and investigative functions, ${ }^{78}$ and detection of crime and prevention of crime ${ }^{79}$ have generally failed, with the result that the rule has been applied to an ever increasing variety of police activity.

\section{Other Jurisdictions}

Unlike the UK, Canadian courts have utilised the tort of negligence to scrutinise police investigatory activity. Originating with $D o e,{ }^{80}$ the courts have declined to follow Hill, and by doing so 'do not appear to have triggered an avalanche of cases'. ${ }^{81}$ The court found that in the peculiar circumstances of Doe, the police owed a duty to warn the plaintiff of the dangers she encountered as a member of a particular class of women, vulnerable to attack by a serial rapist. The police, it was held, were aware of the risk posed and as such the requirements of foreseeability and proximity of relationship were satisfied. Policy arguments although argued by the defence, were not applied to deny the duty. ${ }^{82}$

In South Africa and New Zealand courts have also found public policy grounds denying a duty of care unconvincing. ${ }^{83}$ The Constitutional Court of South Africa has noted that the requirements of foreseeability and proximity provide sufficient grounds for limiting liability and provide a sufficient balance to the fears that imposition of a duty may adversely affect the proper exercise of police officers' duties. As the court has noted '[1]iability ... must ... be determined on the basis of the law and its application to the facts of the

\footnotetext{
${ }^{76}$ Hughes [1991] 4 All ER 278.

${ }^{77}$ Brooks [2005] UKHL 24.

${ }^{78}$ Hughes [1991] 4 All ER 278.

${ }^{79}$ Alexandrou v Oxford [1993] 4 All ER 328.

${ }^{80}$ Doe (1998) 160 D.L.R. $\left(4^{\text {th }}\right) 697$.

${ }^{81}$ Hoyano, above n 52, 930.

${ }^{82}$ See Melanie Randell, 'Sex Discrimination, Accountability of Public Authorities and the Public/Private Divide in Tort Law: An analysis of Doe v. Metropolitan (Municipality) Commissioners of Police' (2001) 26 Queen's Law Journal 451.

${ }^{83}$ Carmichele v Minister of Safety and Security (2001) 12 BHRC 60; Whithair v Attorney General (1996) 2 NZLR 45.
} 
case, and not because of an immunity against such claims granted to the respondents. ${ }^{84}$

However, similar to the UK, United States courts have been loathe to impose a duty of care on the basis that to do so interferes with resource decisions which are the realm of the executive. ${ }^{85}$ This 'fundamental principle that a government and its agents are under no general duty to provide public services, such as police protection, to any particular individual citizen, ${ }^{86}$ has supported the public duty doctrine which provides a broad exemption for police from negligence actions. The courts have however recognised that '[q]uite distinguishable, of course, is the situation where the police authorities undertake responsibilities to particular members of the public and expose them, without adequate protection, to the risks which then materialize into actual losses. ${ }^{87}$ Therefore where there is an assumption by the police of an affirmative undertaking to act on behalf of the injured party and the injured party justifiably relies on that undertaking, a duty will arise and public policy considerations (similar to Hill) will have no bearing on the issue. ${ }^{88}$

\section{The Australian Position}

\section{$1 \quad$ High Court}

The High Court has not been required to consider the scope of the duty of care owed by police to individual members of the public; however, broad support is evident for the Hill public policy grounds in a number of judgments. In Sullivan $v$ Moody $^{89}$ where the High Court was examining the duty of care owed by defendants charged with investigation of child sexual abuse to those

\footnotetext{
${ }^{84}$ Carmichele v Minister of Safety and Security (2001) 12 BHRC 60, [49].

${ }^{85}$ Riss $v$ City of New York 2 N.Y. 2d 578; 240 N.E. 2d 897.

${ }^{86}$ Warren v District of Columbia 444 A.2d 1 (D.C. App. 1981).

${ }^{87}$ Riss $v$ City of New York. York 2 N.Y. 2d 578; 240 N.E. 2d 897. See also Warren v District of Columbia Metropolitan Police Id, Anthony Mastroianni v County of Suffolk et al., 91 N.Y. 2d 198, Cuffy v City of New York 69 N.Y. 2d 222, Sorichetti v City of New York, 65 N.Y. 2d 579. Note however De Wald v State, 719 P.2d 643 (Wyo. 1986), Adams v State 555 P. 2d 235 (Alaska, 1976) where the public duty doctrine has been rejected.

${ }^{88}$ See Anthony Mastroianni v County of Suffolk et al., 91 N.Y. 2d 198. While assumption of an undertaking and justifiable reliance are the main elements required to establish a 'special relationship', the courts also require knowledge on part of police that harm could result from failure to act and direct contact between the police and the injured party.
}

${ }^{89}$ (2001) 207 CLR 562. 
under investigation the court stated:

How may a duty of the kind for which the appellants contend rationally be related to functions, powers and responsibilities of the various persons and authorities who are alleged to owe that duty? A similar problem has arisen in other cases. The response to the problem in those cases, although not determinative, is instructive.

In Hill $v$ Chief Constable of West Yorkshire, the House of Lords held that police officers did not owe a duty to individual members of the public who might suffer injury through their careless failure to apprehend a dangerous criminal. Lord Keith of Kinkell pointed out that the conduct of police investigation involves a variety of decisions as to priorities in the deployment of resources. To subject those decisions to a common law duty of care, and to the kind of judicial scrutiny involved in an action in tort, was inappropriate. $^{90}$

In Tame $v$ New South Wales, referring to Hill, Gummow and Kirby JJ commented:

It is unlikely that an investigating police officer owes a duty of care to a person whose conduct is under investigation. Such a duty would appear to be inconsistent with the police officer's duty ultimately based in the statutory framework and anterior common law by which the relevant police service is established and maintained, fully to investigate the conduct in question. $^{91}$

\section{Similarly Hayne J stated}

Police officers investigating possible contravention of the law do not owe a common law duty to take reasonable care to prevent psychiatric injury to those whose conduct they are investigating. Their duties lie elsewhere and to find a duty of care to those whom they are investigating would conflict with those other duties. ${ }^{92}$

\footnotetext{
${ }^{90}$ Ibid [56],[57].

${ }^{91}$ Tame v New South Wales (2002) 211 CLR 540, [231].

${ }^{92}$ Ibid [292].
} 
McHugh $\mathrm{J}$ has been equally supportive of the Hill principles, though again commenting that a person subject to a 'special risk of harm' may fall outside the no-duty rule. ${ }^{93}$ Consistent with these comments, a variety of State cases have held that inconsistent obligations owed to the person under investigation and potential victims operate to deny a duty of care owed by the investigating body to the person under investigation. ${ }^{94}$

In addition to the public policy grounds stated above, where the harm is caused by the criminal acts of a third party, the plaintiff will be required to overcome 'the general rule ... that one man is under no duty of controlling another man to prevent his doing damage to a third ${ }^{95}$ When one considers the High Court's treatment of this principle in Modbury, ${ }^{96}$ and analogous recent state decisions, ${ }^{97}$ it is suggested that this will not be an easy task. Gleeson CJ acknowledged that exceptions may arise where 'the criminal conduct is attended by such a high degree of foreseeability, and predictability, that it is possible to argue that the case would be taken out of the general principle and the law may impose a duty to take reasonable steps to prevent it. ${ }^{98}$ Other relevant factors to consider in determining the applicability of

${ }_{93}^{93}$ D'Orta (2005) 214 ALR 92 [101] and [102].

${ }^{94} \mathrm{See}$, eg, where the investigating body is the police or prosecution authorities Heponstall v Gaskin [2003] NSWSC 693; Cran v New South Wales [2004] NSWCA 92; Courtney v Tasmania [2000] TASSC 83; Ward v Dickson \& Chief Constable [1999] NIQB 8; Elguzouli-Daf v Commissioner of Police of the Metropolis [1995] QB 335; New South Wales v Paige [2002] NSWCA 235; Wilson v New South Wales [2001] NSWSC 869; where the investigatory body is responsible for child welfare, $S B$ $v$ New South Wales [2004] VSC 514;, JD (FC) v East Berkshire Community Health NHS Trust [2005] UKHL 23; Sullivan v Moody (2001) 207 CLR 562, where the investigatory body is the Equal Opportunity Commission, Smith $v$ South Australia [2002] SASC 355 (Supreme Court of South Australia, Full Court, Unreported Judgment).

${ }^{95}$ Smith v Luers (1945) 70 CLR 256 (Dixon J). This principle itself comes from the original concept that unless there is a 'special relationship' warranting an exception to the rule, a person is generally not liable for mere omissions; there is in general no duty to rescue, Stovin v Wise [1996] AC 923 (HL) 943-44.

${ }^{96}$ Modbury (2000) 205 CLR 254.

${ }^{97}$ See, eg, Xv South Australia [2005] SASC 150 where the South Australian Supreme Court held the Parole Board did not owe a duty of care to a young plaintiff who was injured by a notorious paedophile who was under their supervision. The case was distinguished from the earlier case of Swan v South Australia (1994) 62 SASR 532.

${ }^{98}$ Modbury (2000) 205 CLR 254, 267 (Gleeson CJ)(Gaudron J whilst agreeing with Gleeson CJ added '[t]here are situations in which there is a duty of care to warn or take other positive steps to protect another against harm from third parties. Usually a duty of care of that kind arises because of special vulnerability, on the one hand, and 
imposing a duty will include the defendant's ability to control the harm, the plaintiff's vulnerability and assumption of responsibility by the defendant. ${ }^{99}$

\section{$2 \quad$ State Court Decisions}

Recent state and federal court decisions have confirmed the difficulties plaintiffs will face in establishing that a duty of care is owed by police officers to individual members of the public in their investigative functions. The courts differing methodologies demonstrate that, in Australia, the approach to this question is far from clear and consistent.

The following list outlines the circumstances in which the courts have held that no duty of care is owed by police:

1. Where off-duty police officers attending a nightclub witnessed a patron of the club being abusive and violent and failed to act to restrain him prior to his vicious assault on the plaintiff. ${ }^{100}$ This was based upon concerns of indeterminate liability, inconsistent obligations with the public at large and impermissible interference in the operational decisions of police'. ${ }^{101}$ The court acknowledged the strength and support for the Hill public policy considerations, and applied these within the six questions proposed by McHugh $\mathrm{J}$, as applicable to novel duty of care cases concerning statutory authorities. ${ }^{102}$

2. Where police officers alerted an absconding parent that they were aware of her whereabouts, allowing her the opportunity to remove the children from the plaintiff. ${ }^{103}$ The case proceeded on the conceded assumption that Hill provided 'immunity' to police in the conduct of investigations, the argument turned on whether the conduct in question amounted to an investigation. The court also refused an argument that the immunity should not apply as

on the other, special knowledge, the assumption of a responsibility or a combination of both.', 270).

${ }^{99}$ See, eg Cran v New South Wales [2004] NSWCA 92; State of New South Wales $v$ Godfrey [2004] Aust Torts Reports 81-741; Modbury (2000) 205 CLR 254, 270 (Gaudron J); Crimmins v Stevedoring Industry Finance Committee (1999) 200 CLR 1, 39; Graham Barclay Oysters Pty Ltd v Ryan (2002) 211 CLR 540.

${ }^{100}$ Peat v Lin [2004] QSC 219.

${ }^{101}$ Ibid [29].

${ }_{102}$ Crimmins v Stevedoring Industry Finance Committee (1990) 200 CLR 1, [93].

${ }^{103}$ Quintano v New South Wales [2002] NSWSC 278. 
there were no conflicting obligations placed upon the police. The court held conflicting obligations owed to the plaintiff and the absconding parent existed. ${ }^{104}$

3. Where the plaintiff's detention in custody was prolonged due to the failure of police to complete a form requesting prompt analysis of evidence. ${ }^{105}$ The case proceeded on the basis that 'immunity' for police existed in relation to their investigative functions and held that subjecting even ministerial tasks to a duty of care would affect police resources. Thus no exception was warranted. ${ }^{106}$ Assumption of responsibility was acknowledged as a recognised exception, not applicable to the prosecuting authority in this case due to the existence of advocate's immunity. ${ }^{107}$

4. Where the plaintiff as a person under investigation claimed negligence by the police in their investigation and/or prosecution of alleged criminal activity. ${ }^{108}$ These cases have proceeded upon the basis that the inconsistent obligations and duties owed by police to the public and those owed to the individual under investigation militate against a duty of care. However it is interesting to note that once the investigation is complete a duty has been held to exist to advise the convicted person of information that the conviction may have been unsafe. ${ }^{109}$

5. Where the plaintiff claimed psychiatric harm due to failure of the prosecuting authorities to prosecute a person alleged to have assaulted the plaintiff. ${ }^{110}$ This was based upon the inhibiting effect the duty would place upon the discretionary function of prosecutors.

6. Where the plaintiffs claimed psychiatric harm as a result of police negligence in identifying their deceased mothers after a traffic

\footnotetext{
${ }^{104}$ Ibid [41].

${ }^{105}$ Cran v New South Wales [2004] NSWCA 92.

${ }^{106}$ Ibid [50], [51].

${ }^{107}$ Ibid [52].

${ }^{108}$ Wilson v New South Wales [2001] NSWC 869, Heponstall v Brian Gaskin [2003] NSWSC 693, Gibbs v Qld [2000] QCA 33, Courtney v Tasmania [2000] TASSC 83.

${ }^{109}$ Tache $v$ Abboud [2002] VSC 36, where concerns about promoting defensive investigatory conduct, were held not to be relevant once a conviction is reached. Rather to impose a duty after this time, was held to enhance due performance.

${ }_{110}$ Mesinga v Commissioner of Australian Federal Police [2001] ACTSC 46, Grimwade v Victoria (1997) 90 A Crim R 526.
} 
accident, the result being that each of the deceased was identified as the other. ${ }^{111}$ The court held that the detrimental effect of imposing a duty on police investigatory functions applied equally to traffic accident investigations. ${ }^{12}$

7. Where the plaintiff claimed that the defendant's negligent use of information provided to the police by his father, exposed him to the risk of the death penalty. ${ }^{113}$ This was based upon the purpose and function of the police to investigate the matter and the conflicting obligations imposition of a duty would place upon the officers. ${ }^{114}$ Interestingly, Finn $\mathrm{J}$ referring to the differing approaches of the courts in Australia to the question of the existence and scope of police duty of care, commented that: ' $[\mathrm{I}] \mathrm{t}$ is, in my view, unnecessary in this matter to express a concluded view on whether, as in England, a special, though not unqualified, immunity rule applies to police activities "in the investigation and suppression of crime" ... or whether the duty of care question is to be answered by applying to police those principles now generally applied to public authorities in the discharge of their statutory and, if relevant, common law functions'. ${ }^{115}$ Preference was expressed for the latter approach.

A small number of these cases analysed the Hill policy considerations within the duty of care framework adopted by the High Court in dealing with public authorities. ${ }^{116}$ This framework begins with a determination of foreseeability of harm, followed by consideration of salient factors which include examination of the authority's statutory obligations, the defendant's power to protect the plaintiff (control), the vulnerability of the plaintiff, ${ }^{117}$ the defendant's knowledge of the risk of harm, and policy considerations

\footnotetext{
${ }^{111}$ Halech $v$ South Australia [2006] SASC 29. (Unreported judgments).

112 Ibid [59].

${ }^{113}$ Rush v Commissioner of Police [2006] FCA 12 (Unreported judgments).

${ }^{114}$ Ibid [117].

115 Ibid [101].

${ }^{116}$ A number of cases have adopted the six-stage approach propounded by McHugh J in Crimmins v Stevedoring Industry Finance Committee (1999) 200 CLR 1, 39 [93]. See, eg, Peat v Lin [2004] QSC 219; Wilson v New South Wales [2001] NSWC 869.

117 Vulnerability is referred to by McHugh in Crimmins $v$ Stevedoring Industry Finance Committee (1999) 200 CLR 1, [93] 'in the sense that the plaintiff could not reasonably be expected to adequately safeguard himself or herself or those interests from harm'.
} 
including inconsistent obligations. Within this analysis is the recognition that resource allocations and 'quasi-legislative' decision making are not justiciable. $^{118}$

Conversely there are a number of cases where the courts, in effect, adopt the UK approach of applying as a first step an immunity rule to police activity in the investigation and suppression of crime. Under this analysis it is accepted that the 'immunity rule' is not absolute, however the cases demonstrate 'the difficulty in providing criteria to mark out exceptions to [the] immunity'. ${ }^{119} \mathrm{In}$ the UK this has resulted in awkward and sometimes incoherent arguments concerning policy/operational distinctions, ${ }^{120}$ direct and indirect harm, ${ }^{121}$ and the effect of imposing a duty on discretionary decision making. Rather than clarify the law, these cases have only served to further blur the lines between duty and no duty.

In the rare cases where a duty has been held to exist, the courts, while acknowledging that blanket immunity does not exist for police in Australia, have attempted to identify exceptions to the Hill principles to justify the imposition of a duty of care. In the Victorian case of Zalewski $v$ Turcarola, ${ }^{122}$ where the plaintiff was shot and injured by the police, the court considered the defendant's argument that they were immune from liability on the public policy grounds enunciated in Hill. In distinguishing Hill and Osman, the court applied an exception to the 'immunity rule' enunciated by May $\mathrm{J}$ in Hughes $v$ National Union of Mineworkers. ${ }^{123}$ In Hughes, May $\mathrm{J}$ had argued that a duty would attach to incidents involving 'specifically identified antecedent negligence' but not 'operational decisions taken in the course of attempts to control serious public disorder'. ${ }^{124}$ In Zalewski, Hansen J concluded that as the case involved 'specifically identified antecedent negligence' in which the

\footnotetext{
118 Graham Barclay Oysters Pty Ltd v Ryan (2002) 211 CLR 540, [14] (Gleeson CJ).

${ }^{119}$ Rush v Commissioner of Police [2006] FCA 12, [101], (Finn J), referring to The Chief Constable of Northumbria $v$ Costello [1998] EWCA Civ 1898, Cowan v The Chief Constable for Avon \& Somerset Constabulary [2001] EWCA Civ 1699.

${ }^{120}$ A distinction that has been acknowledged is often difficult to draw, see eg Graham Barclay Oysters Pty Ltd v Ryan (2002) 211 CLR 540, [12] (Gleeson CJ).

121 This distinction was referred to as unhelpful in Brooks [2005] UKHL 24, [32] (Lord Steyn).

${ }_{122}$ [1995] 2 VR 562 ('Zalewski').

123 [1991] 4 All ER 278.

124 Ibid 288. This is how May $\mathrm{J}$ distinguished his decision from Rigby $v$ Chief Constable of Northamptonshire [1985] 2 All ER 985.
} 
police officer 'did not act in accordance with his training and instructions', the application of any form of 'immunity' did not exist. ${ }^{125}$ This latter exception was said to be justified by the English decisions in Rigby ${ }^{126}$ and Knightley. ${ }^{127}$

One of the difficulties with this approach is defining what is meant by 'specifically identified antecedent negligence'. Could it not equally be argued that the 'litany of derelictions' of police duty identified in Brooks also amounted to acts of 'specifically identified antecedent negligence'? Or the failure by the police in Cran to complete the request for analysis of the suspected drugs, in accordance with their procedures? These too were clear examples of where the police officers 'did not act in accordance with ... training and instructions'. Is the distinction not more appropriately defined as the difference between direct and indirect harm, a distinction identified as unhelpful by Lord Steyn in Brooks? ${ }^{128}$ Arguably as Zalweski involved direct physical harm to the plaintiff, similar to negligent police driving, the complex policy issues concerning third party harm, competing and inconsistent obligations, and encouraging defensive practices did not arise. ${ }^{129}$ This then begs the question, should this conduct not be classified as police investigatory work as originally envisaged in Hill, so that questions of 'immunity' do not arise? In other cases where parties have suffered direct physical injury as a result of bungled police raids and use of excessive force, no 'immunity' defence has been raised, despite claims based on negligence as well as intentional torts. Why this is so is not entirely clear. ${ }^{130}$ Little attempt has been made by the courts to adequately define what amounts to police conduct in the 'investigation and suppression of crime'. ${ }^{131}$

In attempting to rationalise the distinctions between Zalweski and those authorities applying the Hill policy considerations, Hidden $\mathrm{J}$, in the New South Wales Supreme Court, recently stated:

\footnotetext{
125 [1995] 2 VR 562, 567.

${ }^{126}$ Rigby $v$ Chief Constable of Northamptonshire [1985] 2 All ER 985.

${ }^{127}$ Knightley v Johns [1982] 1 All ER 851.

${ }^{128}$ Brooks [2005] UKHL 24, [32] (Lord Steyn).

${ }^{129}$ Equally an action in battery could have been initiated.

${ }^{130}$ See, eg, Victoria $v$ Horvath [2003] VSCA 24 and in particular the comments by Hayne J in Horvath $v$ Victoria [2004] HCA Trans 215, where he questions whether a duty of care was applicable to the case.

${ }^{131}$ See, eg, Quintano v New South Wales [2002] NSWCA 278.
} 
What may set Zalewski and the present case [also concerned with a police shooting of a mentally disturbed man] apart from the other authorities is that the police were not engaged in an investigation in the ordinary sense. Rather, their task was to prevent a possible breach of the peace and to restrain a mentally disturbed person from harming himself and others. Whether that is a relevant distinction is not immediately apparent. ${ }^{132}$

A case that squarely raised the complex issues of liability for third party criminal harm and Hill public policy considerations was the decision of the Supreme Court of Tasmania in Batchelor $v$ The State of Tasmania. ${ }^{133}$ Blow J refused to strike out the plaintiff's statement of claim, which alleged police negligence in failing to protect the plaintiff's mother from the fatal shooting by his father. Prior to the shooting the mother had sought assistance from the police for assaults and threats made to her by the father. While at the police station, the father entered and was told that he would be served with a restraining order. In apparent disregard of the 'pro-charge pro-arrest' policy then in force, the police did not arrest the father for the purpose of issuing a restraining order, but instead advised him they were taking the mother to the matrimonial residence to collect her belongings and confiscate his firearms. After leaving the police station, the father travelled to the home where he took one of the firearms and lay in wait. Despite noticing the firearm was missing, the police did not evacuate the property, and the father carried out his threats by shooting the mother and then himself.

Relying on the possible exceptions to the general 'no-duty' rule for harm caused by third parties, referred to by Gleeson CJ in Modbury, ${ }^{134}$ Blow J held that the situation carried a high degree of 'foreseeability'. Further as the police had assumed responsibility for the safety of the mother, who was clearly vulnerable ${ }^{135}$ (at least in the short term while collecting her belongings), had taken control of the situation and had the ability to control the father (again at least in the short term) it was arguable that a duty may arise. It is suggested that in these circumstances the decision is clearly justified.

\footnotetext{
${ }^{132}$ Klein v New South Wales [2005] NSWSC 1341 (Unreported Judgments), emphasis mine.

133 [2005] TASSC 11 ('Batchelor').

${ }_{134}$ Modbury (2000) 205 CLR 254, [30], [34].

${ }^{135}$ Vulnerability in this sense refers to her relationship with the defendants. She was dependent on their ability to protect her and vulnerable to their response to her situation.
} 
Blow J's treatment of the defendants' argument that they were immune from a duty of care on policy grounds is less convincing. Acknowledging 'that it remains to be seen' whether Australian courts would follow the authority establishing a 'doctrine of immunity' in the UK, Blow J interpreted the English authorities as proposing that the immunity 'as held in Hill ... is not available to a police officer who has acted otherwise than in accordance with his or her training and instructions. ${ }^{, 136}$ Relying primarily on the judgment in Zalewski, Blow $\mathrm{J}$ held that as it was arguable the police had failed to act in accordance with their training by not following the pro-arrest pro-charge policy, the 'immunity' did not apply.

For the same reasons as stated above, this distinction is unhelpful. Many instances of police negligence will arise out of a failure to act in accordance with training and instructions and yet, under UK authority, no duty has been held to exist. A preferable approach, it is submitted, would have been to analyse the application and appropriateness of the various policy grounds within the duty of care framework applicable to public authorities to determine if they warranted a finding of 'no-duty'. The issues of assumption of responsibility, ${ }^{137}$ control and vulnerability in this case, would have operated to negate concerns of inconsistent obligations and effectively limited indeterminacy. It is suggested that Blow J's approach, despite acknowledging there is no blanket immunity for police negligent conduct, incorrectly begins from the premise that 'immunity' in some form exists, from which exceptions must be found.

\section{Where To From Here?}

Australian appellate courts are poised to define precisely how to apply the Hill public policy considerations. The proliferation of recent novel cases in this area and the diversity of judicial approaches confirm that a coherent body of law providing clear and authoritative guidelines is yet to be established. As has been demonstrated in part three, the UK approach of applying a qualified 'doctrine of immunity' from which exceptions are argued has led to differing and sometimes inconsistent justifications. This approach, it is argued, should be avoided.

${ }^{136}$ Batchelor [2005] TASSC 11, 24, relying on Knightley v Johns [1982] 1 All ER 851; Rigby v Chief Constable of Northamptonshire [1985] 2 All ER 985and Zawelski [1995] 2 VR 562.

${ }^{137}$ As stated above, assumption of responsibility for a particular plaintiff's safety, as opposed to the public at large, has been recognised in the UK and US jurisdictions as warranting an exception to the 'immunity' rule. 
The opportunity also exists for Australian courts to reassess a number of the policy principles in light of recent decisions and findings in other jurisdictions. Lord Keith's decision in Hill was influenced, at least in part, by the barrister's immunity then in force. This 'immunity' was justified by a concern that to impose a duty of care would lead to defensive practices detrimentally affecting police activities. This argument must now be of doubtful validity given decisions in the United Kingdom and Australia regarding barrister's immunity. ${ }^{138}$

Although research has suggested that police do hold genuine fears of litigation, ${ }^{139}$ other research has argued the impact of fear on police performance and willingness to act has been exaggerated. ${ }^{140}$ In relation to advocate's immunity, the majority in D'Orta acknowledged that although arguments that imposition of liability would lead to defensive practices were not irrelevant, they were also 'not of determinative significance.' 141

Of greater significance is the compelling argument that the fear of litigation promotes better policing practices. ${ }^{142}$ As has been noted, 'nothing more effectively focuses the mind and hence improves the quality of decisions by a police officer than the knowledge that the decision may be subject to scrutiny

\footnotetext{
${ }^{138}$ In the UK the public policy grounds relied on in Hill as applied to barristers has since been abolished in Hall v Simon [2000] 3 WLR 543. In D'Orta, the majority has dismissed a number of the original policy grounds said to justify the immunity. See also the view that this was not applicable to teachers in Phelps $v$ Hillingdon London Borough Council [2000] 4 All ER 504.

${ }^{139}$ S. Jellerr, N.K. Pope and K.E. Voges 'The Stress of Litigation' (1994) Australian Police Journal 163; Forrest Scogin, Stanley Brodsky 'Fear of Litigation Among Law Enforcement officers', (1991) X (1) American Journal of Police 41.

${ }^{140}$ See, eg, Civil litigation by citizens against the Australian Police between 1994 and 2002, Report to the Criminology Research Council, by Dr Jude McCulloch and Mr Darren Palmer. CRC Grant No 19/01-02, Current Commentary, Australasian Centre for Policing Research, No 5 Nov 2002 [1] - 11, www.acpr.gov.au/pdf/ACPR_cc5.pdf accessed 6.3.06; Tony Zalewski, 'Litigation in Law Enforcement', Security Oz; Number 15; February/March 2002; 076-081; David Brereton, 'Monitoring Integrity' in Tim Prenzler and Janet Ransley (eds), Police Reform Building Integrity (2002) 99, 113.

${ }^{141}$ D'Orta (2005) 214 ALR 92, [29].

${ }^{142}$ See eg, Tom Hughes, 'Police officers and civil liability: "the ties that bind"?' (2001) 24 Policing: An International Journal of Police Strategies and Management' 240, 245; McCulloch and Palmer above n 140.
} 
by a court of law. ${ }^{143}$ Lord Keith's argument that 'the general sense of public duty which motivates police forces is unlikely to be appreciably reinforced by imposition of such liability' was premised on the basis that police always apply their best endeavours to their public duty, a sentiment, which as the court acknowledged in Brooks, is no longer universally accepted. Police corruption and misconduct are still of major concern in Australian police forces and public dissatisfaction with police complaints mechanisms has been seen as a contributing factor to the increase in civil litigation against police and a driving force for demands for greater transparency and accountability. ${ }^{144}$

Concerns of encouraging defensive practices, once raised in an attempt to limit medical negligence claims, have long since been rejected. There is no suggestion that law enforcement, in jurisdictions where Hill public policy grounds have not been imposed to deny a duty, has been detrimentally affected in this way.

Underlying these arguments is the assumption that negligence actions against the police are relatively easy to initiate and that rejection of such policy considerations will 'open the floodgates'. ${ }^{145}$ On current authority this is clearly not the case. Concerns of indeterminate liability can be addressed within the framework of the High Court's 'astute use of the vulnerability concept', ${ }^{146}$ which will require proof that the plaintiff is at a distinctive risk, as opposed to the general public, and the defendant has the ability to control the source of harm or has assumed responsibility for the plaintiff's safety. The limits thus placed on duty of care will effectively counter arguments that valuable police resources will be diverted from policing activities to defend unmeritorious claims. ${ }^{147}$

\footnotetext{
${ }^{143}$ Marcus Tregilgas-Davey's 'Osman v Metropoitan Police Commissioner: The Cost of Police Protectionism' (1993) 56 (5) The Modern Law Review 732, 735.

${ }^{144}$ See eg,. McCulloch above n 140, 10.

${ }^{145}$ Melanie Randell, 'Sex Discrimination, Accountability of Public Authorities and the Public/Private Divide in Tort Law: An analysis of Doe v. Metropolitan (Municipality) Commissioners of Police' (2001) 26 Queen's Law Journal 451, 487.

${ }^{146}$ Jane Stapleton 'The golden thread at the heart of tort law; protection of the vulnerable', (2003) 24 Australian Bar Review 135, 139.

${ }^{147}$ Note a similar argument was rejected by the House of Lords in relation to education authorities and the duties owed to their pupils in meeting their special educational needs in Phelps v Hillingdon London Borough Council [2000] 4 All ER 504.
} 
Police investigatory work by its nature involves a great deal of discretionary decision making. Concern that many such decisions 'would not be regarded by the courts as appropriate to be called in question" ${ }^{\text {, }} 48$ can be adequately dealt with by consideration of the statutory and common law functions of the public authority. Where an authority charged with investigatory functions owes inconsistent obligations to the particular plaintiff and the general public, the balancing of competing obligations will favour the public and no duty of care to the particular plaintiff will be owed. Where the plaintiff is a person under investigation it is accepted that imposition of a duty of care would in many circumstances involve inconsistent obligation, a 'countervailing factor' that will be difficult to surpass on current authority. ${ }^{149}$ Furthermore due to the competing demands on police it could be argued that 'the standard of care that ... courts would require before they found that a duty of care had been breached would be high and would ... act as one (of many) controlling devices against an open-ended liability'. ${ }^{150}$ Balancing of competing factors at the breach stage and difficulties associated with causation, particularly when concerned with third party criminal harm, would effectively limit liability in many cases.

High level policy decisions and resource issues would not, on current authority, be justiciable. ${ }^{151}$ Although distinguishing between policy and operational decisions is often difficult and is not universally favoured by the High Court, ${ }^{152}$ such considerations would still provide limits on duties to be imposed.

\footnotetext{
${ }^{148}$ Hill [1989] AC 53, 55 (Lord Keith).

${ }^{149}$ For an opposing view that is certainly not without merit, that these issues are better dealt with as a question of breach, see Elizabeth Handlsey 'Sullivan v Moody: Foreseeability of injury is not enough to found a duty of care in negligence - but should it be?' (2003) 11 Torts Law Journal 1.

${ }_{150}$ Basil Markesinis, 'Plaintiff's tort law or defendant's tort law? Is the House of Lords moving towards a synthesis?' (2001) 9(2) Torts Law Journal 168, referring to the duty owed by education authorities to children in relation to their special educational needs.

${ }_{152}^{151}$ Graham Barclay Oysters Pty Ltd v Ryan (2002) 211 CLR 540, [14] (Gleeson CJ).

${ }^{152}$ Ibid.
} 


\section{A Civil Liability Legislation}

Further safeguards for police authorities have been included within the Civil Liability Acts ${ }^{153}$ provisions which provide 'principles' to be applied in determining 'whether a public or other authority has a duty of care or has breached a duty of care. ${ }^{154}$ The provisions confirm that the general allocation of resources is not justiciable and that the functions required to be exercised must be considered in light of budgetary and resource constraints and by reference to 'the broad range of its activities'. ${ }^{155}$ This is consistent with the current common law approach.

Under the provisions an authority will be able to rely on compliance of its 'general procedures and applicable standards ... as evidence of the proper exercise of its functions. ${ }^{156}$ In NSW and Qld further protection is afforded to authorities in that they will not be liable for the wrongful exercise of, or failure to exercise, a statutory function 'unless the act or omission was in the circumstances so unreasonable that no public or other authority having the functions of the authority in question could properly consider the act or omission to be a reasonable exercise of its functions. ${ }^{157}$ The effect of these provisions will provide the police with a defence to all but the most unreasonable exercises of their duties.

\section{CONCLUSION}

This article has sought to explain the extent of police liability for negligent conduct in Australia. It has confirmed that while in Australia police do not enjoy blanket immunity from liability there is strong support for the broad 'no-duty' approach adopted in the United Kingdom. It has urged caution in applying the extent of the policy grounds first enunciated in Hill, and suggested that the current approach of the High Court to the duty owed by public authorities charged with investigative functions provides sufficient

\footnotetext{
153 In all jurisdictions other than Northern Territory and South Australia similar provisions regarding the duty and scope of public authorities have been enacted. See Civil Liability Act 2002 (NSW) s 40; Civil Law (Wrongs) Act 2002 (ACT) s110; Civil Liability Act 2003 (Qld) s35; Civil Liability Act 2002 (Tas) s 38; Wrongs Act 1958 (Vic) s83, Civil Liability Act 2002 (WA) s5W.

${ }_{154}$ Civil Liability Act 2003 (Q1d) s35.

${ }^{155}$ Civil Liability Act 2003 (Q1d) s35.

${ }^{156}$ Civil Liability Act 2003 (Q1d) s35.

${ }^{157}$ Civil Liability Act 2003 (Qld) s36 (2), Civil Liability Act 2002 (NSW) s 43A.
} 
safeguards to indeterminate liability. Policy considerations that are particular only to police officers, such as the fear of defensive practices, need to be carefully reassessed.

It is suggested that policy factors operating to deny a duty of care owed by police officers must be clearly articulated and justified to avoid unwarranted elevation to a broad exclusionary rule. Where a broad 'no-duty' rule is applied, difficulties arise in attempts to justify exceptions, often on inconsistent and spurious grounds. This it is argued is contrary to 'the development of a principled, general law of negligence'. ${ }^{158}$

Recent Australian state court decisions dealing with police negligence have attempted to reconcile the various approaches to the Hill principle adopted in the UK, often becoming entangled in complex argument about the type of police conduct involved. Such distinctions have only served to blur the lines between duty and no-duty, providing little guidance to potential plaintiffs and police departments concerned to minimise risk. While the search for a single unified duty of care formula may be unattainable, principles applicable to public authorities have, it is argued, developed sufficiently to provide a consistent approach to police negligence actions.

For this area to develop in a principled way, it is suggested that once foreseeability is established, exploration of the policy considerations applicable to public authorities charged with investigative functions must be clearly articulated and care taken to ensure that issues of control, vulnerability and assumption of responsibility are adequately considered. Courts should avoid reference to 'police immunity' as it masks the fact that there are circumstances where judicial scrutiny of police conduct is warranted. In an age of increasing police investigatory powers caution must be exercised to ensure that civil rights infringements are balanced against the pursuit of alleged criminal activity.

\footnotetext{
${ }^{158}$ Joachim Dietrich 'Duty of care under the 'Civil Liability Acts' (2005) 13(1) Torts Law Journal 17, 22.
} 